\title{
Efektivitas Ekstrak Etanol Biji Pinang Terhadap Densitas GLUT4 pada Sel-Sel Otot Rangka Mencit yang Terinduksi Hiperglikemia
}

\author{
Effectiveness of The Ethanol Extract of Betel Nut on The \\ GLUT4 Density in Skeletal Muscle Cells of Mice Induced \\ Hyperglycemia
}

\author{
MULIA SAFRIDA SARI ${ }^{1}$, AHMAD RIDWAN ${ }^{{ }^{*}}$ \\ ${ }^{I}$ Sekolah Ilmu dan Teknologi Hayati, Institut Teknologi Bandung, Labtek XI, \\ Jl. Ganesha 10, Bandung 40132
}

Diterima 07 Oktober 2016/Disetujui 19 November 2016

\begin{abstract}
Betel nut (Areca catechu) was proven to have antihyperglycemic activity through increased PI3K pathway in the GLUT4 translocation in cells. However, research on the ethanol extract of betel nut in Indonesia is still limited. The main problem in this study was whether the ethanol extract of betel nut could improve glucose tolerance in a two-hour postprandial period and whether the ethanol extract of betel nut could induce GLUT4 translocation in skeletal muscle cells of mice induced hyperglycemia. Glucose tolerance test results showed that treatment of the ethanol extract of betel nut for 24 days with all doses tested: P50,100,150,200 and $250 \mathrm{mg} / \mathrm{kg}$ body weight could improve glucose tolerance in a two-hour postprandial period. The protein electrophoresis of that fasting and one hour postprandial state treatments resulted an increase in GLUT4/BActin density ratio of P250 group compared to negative and positive controls. In

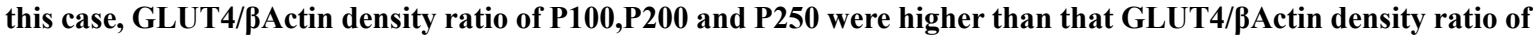
$P 50$ and P150. Increased in GLUT4/BActin density ratio showed enhancement of the GLUT4 in skeletal muscle cells in fasting and one hour postprandial state after treated with ethanol extract of betel nut.
\end{abstract}

Key words: Hyperglycemia, Betel nut, Areca catechu, GLUT4.

\section{PENDAHULUAN}

Secara normal, glukosa merupakan substrat dan sumber energi yang akan dikonversi menjadi ATP melalui proses glikolisis, siklus krebs dan fosforilasi oksidatif di dalam mitokondria. Namun ketika glukosa berlebihan di dalam sel, senyawa ini dapat bersifat toksik yang menginduksi stress oksidatif sehingga menimbulkan kerusakan sel, jaringan bahkan organ. Kelebihan glukosa ini dikenal dengan hiperglikemia. Dalam kondisi kronis, hiperglikemia dapat mengakibatkan penyakit diabetes. Kondisi hiperglikemia didiagnosis ketika konsentrasi glukosa plasma dalam keadaan puasa secara konsisten $\geq 7$ $\mathrm{mmol} / 1(126 \mathrm{mg} / \mathrm{dl})$ atau ketika konsentrasi glukosa plasma setelah 2 jam mengkonsumsi 75 gr glukosa secara konsisten $\geq 11,1 \mathrm{mmol} / 1(200 \mathrm{mg} / \mathrm{dl}$ ) (Brownlee 2005; Giugliano et al. 2008).

Diabetes kini dianggap sebuah epidemik, dengan populasi penderita diperkirakan meningkat hingga

*Penulis korespondensi : +62-22-251 1575

E-mail: ridwan@sith.itb.ac.id
380 juta pada tahun 2025 dan mencapai 429 juta pada tahun 2030 bahkan hingga 642 juta pada tahun 2040 (Tarr et al. 2013; Wild et al. 2004; IDF 2015). International Diabetes Federation (IDF) melaporkan Indonesia berada di urutan ketujuh negara dengan jumlah penderita diabetes tertinggi pada tahun 2015 . Jumlah penderita diabetes Indonesia diperkirakan akan mencapai 16,2 juta pada tahun 2040 (IDF 2015).

Secara tragis, diabetes dapat mengakibatkan 4,9 juta kematian per tahun (IDF 2015). Hal ini disebabkan komplikasi diabetik meliputi neuropati, disfungsi erektil, nefropati, retinopati, makroangiopati seperti penyakit kardiovaskuler, stroke dan kaki diabetik (King et al. 2016; Ramesh et al. 2015; Mansour et al. 2014; Djrolo et al. 2014). Diabetes bahkan dapat dikaitkan dengan peningkatan mortalitas akibat timbulnya beberapa kanker seperti kanker payudara, kanker usus buntu (colorectal cancer) dan kanker prostat (Spangler \& Kirk 2014).

Diabetes atau hiperglikemia kronis ini dapat dipicu adanya abnormalitas dalam metabolisme glukosa terkait defisiensi insulin. Abnormalitas metabolisme glukosa selanjutnya akan menginduksi pembentukan 
sitokin inflamasi dan peningkatan ROS di dalam tubuh. Sitokin inflamasi dan peningkatan ROS terinduksi hiperglikemia memiliki peran penting terhadap perkembangan resistensi insulin pada otot rangka dan menyebabkan gangguan pada pengangkutan glukosa lebih dari $75 \%$ di dalam tubuh melalui peningkatan proses fosforilasi serin/treonin pada IRS dan PI3K dalam jalur aktivasi protein pengangkut glukosa terutama protein GLUT4 (Glucose transporter type 4) (Wei et al. 2008; King et al. 2016). GLUT4 adalah protein 12 - transmembran yang membantu perpindahan glukosa darah periperal ke dalam sel melewati membran plasma. Pengangkutan glukosa dimediasi GLUT4 ini melibatkan aktivasi jalur PI3K terutama dalam sel-sel otot rangka. Jalur PI3K (Phosphatidylinositol 3-kinase) merupakan jalur penting dalam memediasi efek metabolik insulin. PI3K menstimulasi konversi PIP2 menjadi PIP3, meningkatkan aktivasi AKT melalui fosforilasi serin dan treonin. AKT tidak hanya berperan penting dalam proses pengambilan glukosa oleh jaringan-jaringan target insulin melalui translokasi GLUT4, tetapi juga menstimulasi proliferasi sel-sel $\beta$ di dalam pankreas. Secara tidak langsung, peningkatan translokasi GLUT4 dapat menurunkan hiperglikemia dan menginduksi normoglikemia (Khorami et al. 2015; Elghazi et al. 2007).

Berdasarkan hasil review dari berbagai penelitian, dilaporkan bahwa Areca catechu atau pinang merupakan tanaman antidiabetik yang dapat menurunkan hiperglikemia (Mannan et al. 2014; Govindappa 2015).

Pinang merupakan tanaman herbal yang sering dimanfaatkan masyarakat Aceh untuk pengobatan tradisional. Pinang dilaporkan mengandung senyawa alkaloid arekolin yang memiliki aktivitas antihiperglikemik. Arekolin dapat masuk ke dalam sel-sel otot rangka dengan berikatan pada PAT-1 (proton-coupled amino acid transporter-1) (Voigt et al. 2013; Jensen et al. 2014). Selanjutnya, senyawa alkaloid arekolin mampu menginduksi pengambilan 2-deoksiglukosa dalam L6 myotube melalui peningkatan ekspresi GLUT4 dan gen-gen yang terlibat dalam jalur PI3K terkait proses translokasi GLUT4 (Prabhakar \& Doble 2011).

Polifenol seperti epicatechin dan asam siringat dalam ekstrak etanol biji pinang juga memiliki aktivitas antioksidan (Zhang et al. 2014). Senyawa ini dibuktikan mampu menginduksi ekspresi protein GLUT4 pada membran sel otot rangka (Pradini 2010). Senyawa lain yang dijumpai melimpah di dalam pinang adalah golongan hidrokarbon alkana (hexadekana dan heptadekana) dapat menghambat kerja aldosa reduktase melalui pengikatan energi yang besar sehingga enzim tersebut tidak dapat mengikat energi untuk aktivitasnya dalam jalur poliol dan ROS tidak terbentuk (Aleykutty 2012).

Namun, hingga saat ini penelitian mengenai efektivitas pinang terhadap diabetes masih belum banyak dilakukan di Indonesia. Oleh karena itu, penelitian ini penting dilakukan untuk melihat efek pemberian ekstrak etanol biji pinang terhadap translokasi GLUT4 pada keadaan hiperglikemia sehingga dapat memperkuat informasi mengenai khasiat biji pinang.

\section{BAHAN DAN METODE}

Sampel. Biji pinang diperoleh dari Apotik Bunda Langsa Aceh, sedangkan mencit-mencit yang digunakan sebagai sampel dalam penelitian ini diperoleh dari rumah pemeliharaan hewan SITH ITB dengan mengikuti sidang etik sebelumnya.

\section{Metode Penelitian meliputi :}

Ekstraksi dan Analisis Fitokimia. Biji pinang kering $500 \mathrm{~g}$ dihaluskan, dimaserasi dengan pelarut etanol 96\% selama $3 \times 24$ jam. Kemudian maserat difiltrasi, dievaporasi dengan rotary evaporator pada suhu $60^{\circ} \mathrm{C}$ untuk diperoleh ekstrak kental. Ekstrak ini dipanaskan di atas penangas air (waterbath) hingga pelarut menguap sempurna lalu digerus menjadi bubuk. Hasil ekstraksi dalam bentuk ekstrak kasar ini dilarutkan dalam etanol dan diidentifikasi senyawa - senyawa penyusunnya menggunakan uji GCMS (gas chromatography - mass spectrometry) di Laboratorium AKABogor.

Penentuan Dosis Berdasarkan Toksisitas Akut Biji Pinang (LD50). Penentuan dosis yang aman diaplikasikan kepada hewan model didasari oleh penelitian yang telah dilakukan sebelumnya. Sa'roni \& Adjirni (2005) melaporkan bahwa toksisitas akut (LD50) biji pinang terhadap mencit adalah 4,14 $(3,13-5,18) \mathrm{mg} / 10 \mathrm{~g} \mathrm{BB}$ atau $414(313-518) \mathrm{mg} /$ kg BB, sedangkan Pichini et al. (2010) menetapkan bahwa penginjeksian ekstrak alkoholik anhidrat biji pinang dengan dosis $0,5,1$ dan $3 \mathrm{~g} / \mathrm{kg}$ secara oral pada mencit hanya menunjukkan toksisitas akut yang kecil meskipun dapat menimbulkan reflek kornea, ataksia dan peningkatan ritme pernapasan namun penginjeksian oral ekstrak alkoholik anhidrat dengan dosis $100 \mathrm{mg} / \mathrm{kg}$ secara kronis selama tiga bulan menyebabkan peningkatan mortalitas. Berdasarkan nilai toksisitas akut ini, dosis yang aman digunakan terhadap mencit adalah kurang dari $313-518 \mathrm{mg} / \mathrm{kg}$ BB yaitu $50 \mathrm{mg} / \mathrm{kg} \mathrm{BB}, 100 \mathrm{mg} / \mathrm{kgBB}, 150 \mathrm{mg} / \mathrm{kg} \mathrm{BB}$, $200 \mathrm{mg} / \mathrm{kgBB}$ dan $250 \mathrm{mg} / \mathrm{kgBB}$.

Persiapan Hewan Model. Hewan model dalam penelitian ini adalah mencit jantan (Mus musculus $L$ ) galur Swiss Webster yang telah diadaptasikan dengan kondisi kandang selama 7 hari, dipelihara pada suhu 24 $-29^{\circ} \mathrm{C}$ dan diberipakan standar sebanyak $10 \% \mathrm{BB}$ dan air minum. Beberapa mencit diinduksi hiperglikemia dengan menginjeksikan streptozotosin single dose 
dengan dosis $150 \mathrm{mg} / \mathrm{kg}$ BB secara intraperitoneal selama 15 hari. Mencit - mencit yang memiliki kadar glukosa $>200 \mathrm{mg} / \mathrm{dl}$ digunakan sebagai hewan model hiperglikemia.

Pengaruh Ekstrak Etanol Biji Pinang pada Toleransi Glukosa Hewan Model . Mencit - mencit dikelompokkan menjadi 8 kelompok antara lain: kontrol normal (kelompok mencit normal yang diberikan akuabides), kontrol positif (kelompok mencit hiperglikemia yang diberikan metformin), kontrol negatif (kelompok mencit hiperglikemia tanpa diberikan ekstrak etanol biji pinang) dan lima kelompok perlakuan (kelompok mencit hiperglikemia yang diberikan ekstrak etanol biji pinang pada dosis yang berbeda) : P50 (diberikan ekstrak etanol biji pinang dengan dosis $50 \mathrm{mg} / \mathrm{kg} \mathrm{BB}$ ), $\mathrm{P} 100$ (diberikan ekstrak etanol biji pinang dengan dosis $100 \mathrm{mg} /$ kg BB), P150 (diberikan ekstrak etanol biji pinang dengan dosis $150 \mathrm{mg} / \mathrm{kg} \mathrm{BB}, \mathrm{P} 200$ (diberikan ekstrak etanol biji pinang dengan dosis $200 \mathrm{mg} / \mathrm{kg} \mathrm{BB}$ ) dan P250 (diberikan ekstrak etanol biji pinang dengan dosis $250 \mathrm{mg} / \mathrm{kg} \mathrm{BB}$ ). Kedelapan kelompok mencit diberi perlakuan ekstrak etanol dari biji pinang selama 24 hari secara oral gavage. Setelah 24 hari dilakukan pemeriksaan terhadap kadar glukosa darah dalam keadaan puasa, satu jam dan dua jam setelah penginjeksian glukosa oral (postprandial) untuk menguji toleransi glukosa dan densitas protein $\beta$ aktin serta GLUT4.

Pengaruh Ekstrak Etanol Biji Pinang terhadap Densitas Protein Transporter Glukosa GLUT4 pada Sel Otot Hewan Model. Pengukuran densitas protein $\beta$ aktin dan transporter glukosa GLUT4 dalam penelitian inimengikutimetode yang dilakukan oleh Thamotharan et al.(2003) dan Pradini (2010).

Isolasi protein GLUT4. Mencit-mencit pada tiap kelompok penelitian dikelompokkan menjadi dua subkelompokuntuk di-euthanasia dalam chamber $\mathrm{CO}_{2}$ $100 \%$, yaitu subkelompok yang di-euthanasia dalam keadaan puasa dan subkelompok yang di-euthanasia dalam keadaan setelah 1 jam pemberian glukosa oral. Otot-otot pada setiap subkelompok mencit diisolasi dari bagian paha (regio femoralis), disimpan dalam tabung cryotube untuk dibekukan dalam nitrogen cair pada suhu $-190^{\circ} \mathrm{C}$. Otot-otot dari subkelompok yang sama dipindahkan ke dalam mortar berdiameter $8 \mathrm{~cm}$ terisi $15 \mathrm{ml}$ buffer sukrosa yang terdiri dari $250 \mathrm{mM}$

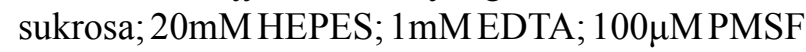
dan 7,5mM Tris. Segera setelah otot dipipihkan dan buffer sukrosa dibuang, nitrogen cair dituangkan ke dalam mortar untuk menghancurkan jaringan otot. Otot yang telah halus dilarutkan dalam $30 \mathrm{ml}$ buffer sukrosa dan selanjutnya dipindahkan ke dalam tabung sentrifugasi $40 \mathrm{ml}$ (Sorval $40 \mathrm{ml}$ ). Suspensi dikocok terlebih dahulu supaya homogen sebelum disentrifugasi menggunakan Superspeed Centrifuge (Sorval RC-5B plus) dengan kecepatan $3000 \mathrm{~g}$ pada suhu $4^{\circ} \mathrm{C}$ selama 10 menit. Supernatan yang terbentuk dipisahkan untuk kuantifikasi konsentrasiprotein total dan deteksi protein $\beta$-aktin.

Pelet yang terbentuk dicuci sebanyak dua kali dengan $30 \mathrm{ml}$ Tris- $\mathrm{HClpH} 8,0$ dan disentrifugasi dengan kecepatan $3000 \mathrm{~g}$ pada suhu $4^{\circ} \mathrm{C}$ selama 10 menit. Pelet dari hasil sentrifugasi ini dilarutkan dengan $15 \mathrm{ml}$ Tris$\mathrm{HCl} \mathrm{pH} \mathrm{8,0} \mathrm{lalu} \mathrm{dihomogenisasi} \mathrm{menggunakan} \mathrm{teflon}$ homogenizer. Suspensi dipindahkan ke dalam beaker glass $40 \mathrm{ml}$ dan ditutup dengan aluminium foil dibiarkan selama \pm 16 jampada suhu $4^{\circ} \mathrm{C}$. Homogenat ditambahkan dengan $200 \mu \mathrm{LiBr} 50 \mathrm{mM} / 10 \mathrm{ml}$ suspensi, lalu diaduk menggunakan plate stirrer selama 2,5 jam pada suhu $4^{\circ} \mathrm{C}$. Homogenat ini kemudian dipindahkan ke tabung sentrifugasi dan ditambahkan dengan $15 \mathrm{ml}$ Tris- $\mathrm{HCl}$ $\mathrm{pH} 8,0$. Setelah dihomogenkan, suspensi disentrifugasi dengankecepatan $10000 \mathrm{~g}$ padasuhu $4^{\circ} \mathrm{C}$ selama 10 menit. Pelet hasil sentrifugasi dihomogenisasi menggunakan teflon homogenizer dan diresuspensi dengan $15 \mathrm{ml}$ Tris$\mathrm{HCl} \mathrm{pH} \mathrm{8,0.} \mathrm{Suspensi} \mathrm{disentrifugasi} \mathrm{kembali} \mathrm{dengan}$ kecepatan 6000 g pada suhu $4^{\circ} \mathrm{C}$ selama 10 menit. Pelet yang terbentuk dihomogenisasi dan diresuspensidengan $15 \mathrm{ml} \mathrm{KBr} 25 \% \mathrm{~B} / \mathrm{V}$, kemudian disentrifugasi dengan kecepatan 10000 g pada suhu $4^{\circ} \mathrm{C}$ selama 30 menit. Pelet dari hasil proses ini dicuci satu kali dengan $10 \mathrm{ml}$ buffer sukrosadan disentrifugasi dengankecepatan 17000gpada suhu $4^{\circ} \mathrm{C}$ selama 20 menit. Hasil akhir pelet dipindahkan ke dalam tabung eppendorf dan disuspensi dengan 100 $\mu l$ buffer sukrosa. Suspensi disonikasi selama siklus $2 \times 50$ detik lalu disentrifugasi kembalidengankecepatan 10000 gpadasuhu $4^{\circ} \mathrm{C}$ selama 10 menit. Supernatanyang terbentuk dipisahkan untuk kuantifikasi konsentrasi protein total dan deteksi protein GLUT4.

Dalam penelitian ini, konsentrasi protein total dikuantifikasi menggunakan metode Bradford dan deteksi protein $\beta$ aktin serta GLUT4 menggunakan elektroforesis kemudian densitas pita kedua protein dikuantifikasi melalui software ImageJ. Selanjutnya nilai densitas pita GLUT4 dibandingkan dengan nilai densitas pita $\beta$ aktin pada setiapkelompokuntuk diperoleh rasio densitas GLUT4/ $\beta$ aktin (Pradini 2010).

Elektroforesis dan pewarnaan protein. Sampel protein sebanyak $\pm 8 \mu$ g dicampur larutan buffer sampel dengan rasio $1: 1$, lalu didenaturasi dalam penangas air (waterbath) pada suhu $95^{\circ} \mathrm{C}$ selama 5 menit. Sampel protein kemudian dimasukkan dalam sumur gel elektroforesis poliakrilamid 10\%. Elektroforesis dilakukan dalam aparatus elektroforesis yang mengandung running buffer dengan tegangan 100 volt hingga sampel proteinyang terwarnaicommasiebrilliant 
blue mencapai batas stacking gel dan separating gel. Tegangan lalu ditingkatkan menjadi 120 volt hingga penanda warna commasie brilliant blue mencapaibatas bawah gel. Protein-protein yang terfraksinasi pada gel elektroforesis diwarnai dengan larutan staining selama 2 jam, kemudian diganti dengan larutan destaining selama 8 jam sampai tampak pita-pita protein.

Deteksi protein GLUT4. Protein GLUT4 dapat diestimasiberdasarkan beratmolekul pita protein yang diperoleh pada gel elektroforesis. Protein GLUT4 memiliki berat molekul antara 50-63 kDa sedangkan protein $\beta$-aktin memiliki beratmolekul $42 \mathrm{kDa}$ (Pradini 2010).

Analisis Statistika. Hasil pengukuran tes toleransi glukosa dalam keadaan puasa, 1 jam dan 2 jam postprandial dianalisis menggunakan Uji ANOVA $(\mathrm{p}<0,05)$ dan dilanjutkan dengan uji Duncan $(\mathrm{p}<0,05)$ untukmengetahuisignifikansiperbedaan rata-ratadengan tingkatkepercayaan $95 \%$.Analisis datainimenggunakan software SPSS 17.0.

\section{HASIL}

Ekstraksi dan Analisis Fitokimia Ekstrak Etanol Biji Pinang. Hasil analisis fitokimia menunjukkan bahwa keberadaan senyawa arekolin di dalam ekstrak etanol biji pinang terdeteksi pada waktu retensi menit ke 11.780 dengan kelimpahan sebanyak 7.447.753 atau $12,904 \%$ daritotal keseluruhan senyawa yang terdeteksi dan senyawa golongan hidrokarbon heptadekana pada menit ke 26.067-28.978 dengan kelimpahan sebanyak 10.345.360 - 13.513.877 atau 9,602\% - 11,956\% dari total keseluruhan senyawa yang terdeteksi (Gambar 1).

Pengaruh Ekstrak Etanol Biji Pinang pada Toleransi Glukosa Hewan Model. Pemberian ekstrak etanol biji pinang selama 24 hari diketahui dapat memperbaiki toleransi glukosa padamencityang diinduksihiperglikemia. Efektivitas ekstrak etanol biji pinang dibuktikan dengan penurunan kadar glukosa darah pada kondisi dua jam postprandial meskipun masih melebihi level glikemia normal yaitu 350 - 450 $\mathrm{mg} / \mathrm{dl}$. Akan tetapi, kadar glukosa darah tersebut lebih rendah dibandingkan kadar glukosa darah satu jam sebelumnya antara $400-500 \mathrm{mg} / \mathrm{dl}$. Hasil uji F Anova dan uji Duncan menunjukkan bahwa kadar glukosa darah antar kelompok mencit hiperglikemia baik yang diberi maupun tidak diberi ekstrak etanol biji pinang memiliki perbedaan yang signifikan pada kondisi satu jam dan dua jam postprandial $(\mathrm{P}<0,05)$. Berdasarkan hasil tes toleransi glukosa, penurunan kadar glukosa darah yang lebih baik terjadipada kelompok perlakuan yang diberikan ekstrak etanol biji pinang dengan dosis 200 dan 250 mg/kg BB (Gambar 2). Dalam hal ini, efek antihiperglikemik diinduksi oleh arekolin dan heptadekana, melalui penurunan stres oksidatif dan peningkatan keberadaanGLUT4 padasel-selototrangka.

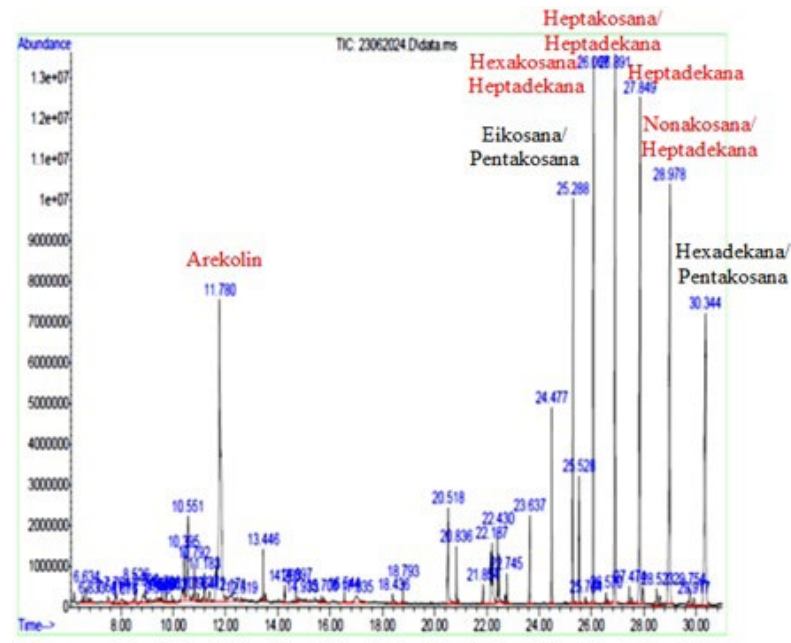

Gambar 1. Hasil GC-MS ekstrak etanol biji pinang

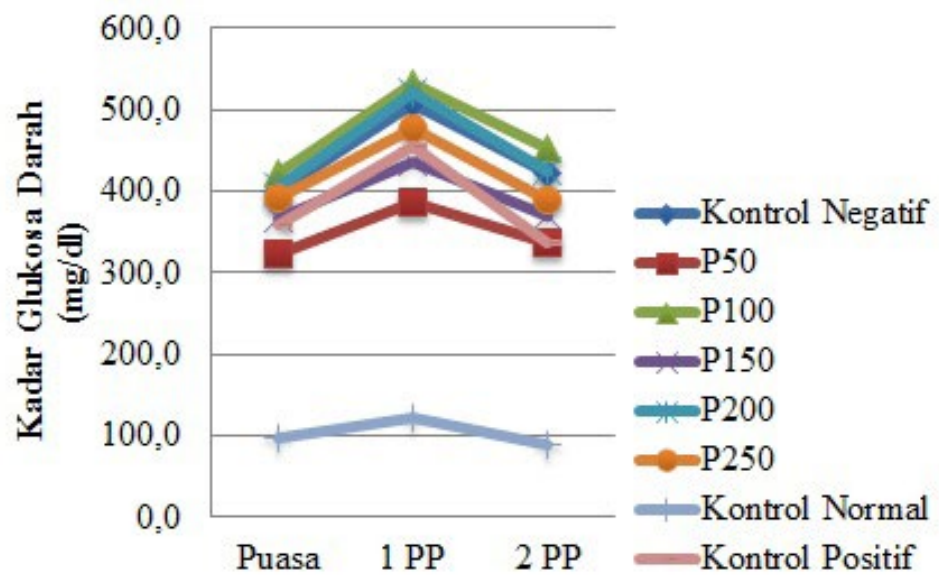

\begin{tabular}{|r|r|}
\hline$\Delta \mathbf{P}-\mathbf{1 P P}(\uparrow)$ & $\Delta \mathbf{1 P P}-2 \mathbf{P P}(\downarrow)$ \\
\hline 105,8 & 83,8 \\
\hline 63,3 & 48,5 \\
\hline 109,3 & 81,0 \\
\hline 68,5 & 64,5 \\
\hline 114,0 & 97,3 \\
\hline 83,8 & 87,3 \\
\hline 24,8 & 32,4 \\
\hline 88,8 & 96,5 \\
\hline
\end{tabular}

Gambar 2. Tes toleransi glukosa tiap kelompok hewan uji yang diberi perlakuan ekstrak etanol berbagai konsentrasi. (Kontrol negatif: kelompok mencit hiperglikemia tanpa pemberian ekstrak etanol biji pinang; kontrol positif: kelompok mencit hiperglikemia yang diberikan metformin (obat antidiabetes); P50: kelompok mencit hiperglikemia yang diberikan ekstrak etanol biji pinang dengan dosis $50 \mathrm{mg} / \mathrm{kg}$ BB; P100: kelompok mencit hiperglikemia yang diberikan ekstrak etanol biji pinang dengan dosis $100 \mathrm{mg} / \mathrm{kg}$ BB; P150: kelompok mencit hiperglikemia yang diberikan ekstrak etanol biji pinang dengan dosis $150 \mathrm{mg} / \mathrm{kg} \mathrm{BB}$; P200: kelompok mencit hiperglikemia yang diberikan ekstrak etanol biji pinang dengan dosis $200 \mathrm{mg} / \mathrm{kg} \mathrm{BB}, \mathrm{P} 250$ : kelompok mencit hiperglikemia yang diberikan ekstrak etanol biji pinang dengan dosis $250 \mathrm{mg} / \mathrm{kg} \mathrm{BB}$; PP: Post prandial (setelah pemberian glukosa oral) 
Pengaruh Ekstrak Etanol Biji Pinang terhadap Densitas Protein Transporter Glukosa GLUT4. Efektivitas ekstrak etanol biji pinang untuk meregulasi pengambilan glukosa ke dalam sel-sel otot melalui proses translokasi GLUT4 dapat pula diamati dari densitas GLUT4 baik dalam keadaan puasa (Gambar 3 dan Gambar 4) maupun 1 jam postprandial (Gambar 5 dan Gambar 6). Hasil kuantifikasi densitas protein tiap kelompok penelitian ini menjelaskan adanya kecenderungan semakin tinggi dosis ekstrak etanol biji pinang yang diberikan maka semakin meningkat pula densitas GLUT4 dalam sel-sel otot.
Meskipun ekstrak etanol biji pinang memiliki efektivitas yang rendah dalam menginduksi pengambilan glukosa, namun rasio densitas GLUT4/ $\beta$ aktin pada kelompok P100, P200 dan P250 diperoleh lebih tinggi dibandingkan kelompok perlakuan yang lain, bahkan kelompok P250 memiliki rasio densitas GLUT4/ $\beta$ aktin yang lebih tinggi dibandingkan kontrol negatif dan kontrol positif baik dalam keadaan puasa maupun 1 jam postprandial (Gambar 4 dan Gambar 6). Meskipun densitas GLUT4 pada kelompok P250 lebih tinggi daripada kelompok kontrol negatif dan kontrol positif, tetapi GLUT4 tersebut diduga tidak fungsional disebabkan sekresi insulin berkurang akibat kerusakan pankreas terkait injeksi streptozotosin dan stres oksidatif.

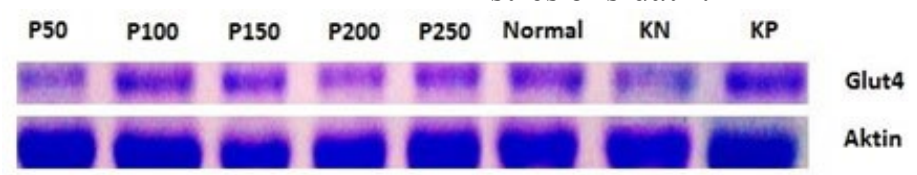

Gambar 3. Densitas protein GLUT4 (50kDa) pada hewan uji dengan perlakuan puasa. Protein aktin digunakan sebagai kontrol. (Kontrol negatif: kelompok mencit hiperglikemia tanpa pemberian ekstrak etanol biji pinang; kontrol positif: kelompok mencit hiperglikemia yang diberikan metformin (obat antidiabetes); P50: kelompok mencit hiperglikemia yang diberikan ekstrak etanol biji pinang dengan dosis $50 \mathrm{mg} / \mathrm{kg}$ BB; P100: kelompok mencit hiperglikemia yang diberikan ekstrak etanol biji pinang dengan dosis $100 \mathrm{mg} / \mathrm{kg} \mathrm{BB}$; P150: kelompok mencit hiperglikemia yang diberikan ekstrak etanol biji pinang dengan dosis $150 \mathrm{mg} / \mathrm{kg} \mathrm{BB}$; P200: kelompok mencit hiperglikemia yang diberikan ekstrak etanol biji pinang dengan dosis $200 \mathrm{mg} / \mathrm{kg}$ BB, P250: kelompok mencit hiperglikemia yang diberikan ekstrak etanol biji pinang dengan dosis $250 \mathrm{mg} / \mathrm{kg} \mathrm{BB}$ ).

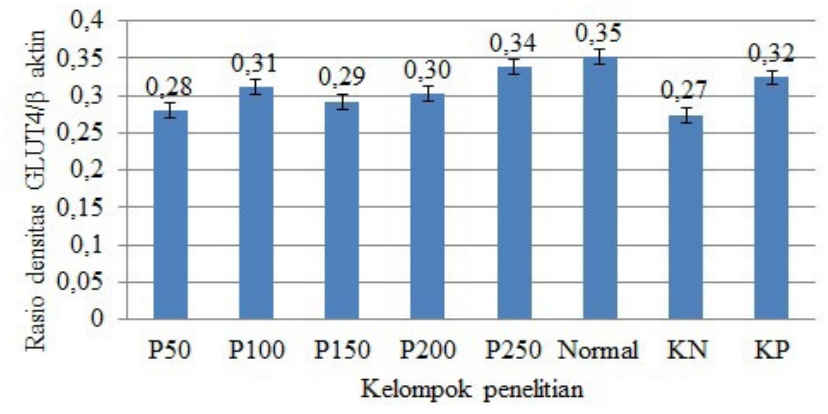

Gambar 4. Rasio densitas GLUT4/ $\beta$ aktin pada hewan uji dengan perlakuan puasa

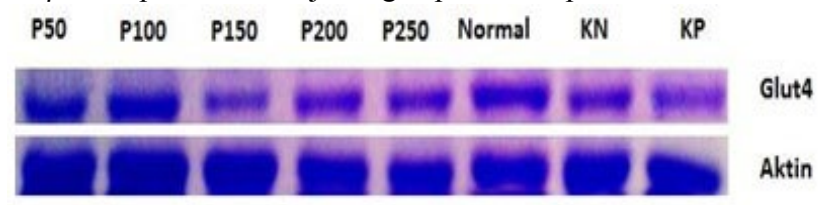

Gambar5. Densitas protein GLUT4 (50kDa) pada hewan uji dengan perlakuan satujam postprandial. Protein aktin digunakan sebagai kontrol. (Kontrol negatif: kelompok mencit hiperglikemia tanpa pemberian ekstrak etanol biji pinang; kontrol positif: kelompok mencit hiperglikemia yang diberikan metformin (obat antidiabetes); P50: kelompok mencit hiperglikemia yang diberikan ekstrak etanol biji pinang dengan dosis $50 \mathrm{mg} / \mathrm{kg}$ BB; P100: kelompok mencit hiperglikemia yang diberikan ekstrak etanol biji pinang dengan dosis $100 \mathrm{mg} / \mathrm{kg} \mathrm{BB}$; P150: kelompok mencit hiperglikemia yang diberikan ekstrak etanol biji pinang dengan dosis $150 \mathrm{mg} / \mathrm{kg}$ BB; P200: kelompok mencit hiperglikemia yang diberikan ekstrak etanol biji pinang dengan dosis $200 \mathrm{mg} / \mathrm{kg} \mathrm{BB}, \mathrm{P} 250$ : kelompok mencit hiperglikemia yang diberikan ekstrak etanol biji pinang dengan dosis $250 \mathrm{mg} / \mathrm{kg} \mathrm{BB}$ ).

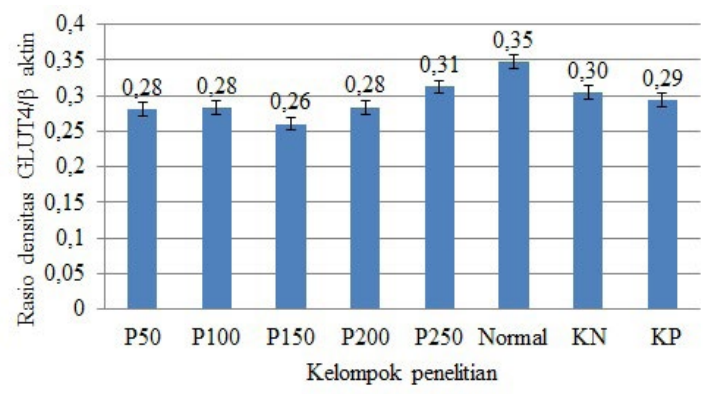

Gambar 6. Rasio densitas GLUT4/ $\beta$ aktin pada hewan uji dengan perlakuan satu jam postprandial 


\section{PEMBAHASAN}

Peningkatan glukosa darah dapat disebabkanadanya defisiensi insulin akibat kerusakan pankreas. Eleazu et al. (2013) menyatakan bahwa streptozotosin mampu menimbulkan kerusakan pankreas secara selektif dengan menghambat aktivitas glikosida hidrolase O-GlcNAcase sehingga menyebabkan glikosilasi pada protein intraseluler dan menginduksi apoptosis sel beta. Hasil pemeriksaan glukosa darah yang diperoleh dalampenelitian iniberbedadenganhasilyang diperoleh Anthikat et al. (2014). Anthikat et al. (2014) membuktikan bahwa ekstrak biji pinang dengan dosis $250 \mathrm{mg} / \mathrm{kg}$ BB dan $500 \mathrm{mg} / \mathrm{kg}$ BB dapat menurunkan kadar glukosa darah setelah dua jam pemberian pada tikus hiperglikemia yang dipuasakan terlebih dahulu. Berbeda dengan penelitian tersebut, pada penelitian ini efek antihiperglikemia ekstrak etanol biji pinang terhadap mencit hiperglikemia diteliti dengan melihat toleransimencithiperglikemia terhadap glukosa setelah pemberian ekstraketanolbijipinang selama24hari. Hasil tes toleransi glukosa pada penelitian ini menunjukkan bahwa pemberian ekstrak etanol biji pinang selama 24 hari dengan dosis 50, 100, 150, 200 dan $250 \mathrm{mg} /$ $\mathrm{kg}$ BB berperan memperbaiki toleransi glukosa pada periode dua jam postprandial terutama dosis 200 dan $250 \mathrm{mg} / \mathrm{kg} \mathrm{BB}$. Dapat diduga bahwa ekstrak etanol biji pinang mampu menginduksi homeostatik intrinsik terhadap kadar glukosa darah meskipun masih berada di atas level glikemia normal yang disebabkan level toksisitas glukosa yang sangat tinggi terkait kondisi hiperglikemia. Selain itu, ekstrak etanol biji pinang dapatberperan dalammeningkatkan translokasiGLUT4 pada sel-sel otot rangka mencit yang diinduksi menjadi hiperglikemiamelaluipeningkatanjalurPI3K(Prabhakar \& Doble 2011)meskipun efektivitasnya rendah dalam menginduksi pengambilan glukosa. Peningkatan rasio densitas GLUT4/ $\beta$ aktin diduga disebabkan kandungan arekolin dalam ekstrak etanol biji pinang yang mampu menginduksi translokasi GLUT4.
Selain arekolin, senyawa hexadekana danheptadekana dalam ekstrak juga diduga dapat menghambat pembentukan ROS sehingga translokasi GLUT4 pada sel-sel otot rangka dapat terjadi.Aleykutty (2012) melaporkanbahwa senyawahexadekanadanheptadekana dapat menghambat aktivitas enzim aldosa reduktase yang secara tidak langsung mengurangi antioksidan intraseluler dalamjalur poliol, melalui pengikatan energi dalamjumlah besar sehingga enzim tersebut tidak dapat melakukan aktivitas dan pembentukan ROS di dalam sel dapat tereduksi. Ketika stres oksidatif intraseluler berkurang, jalur-jalur yang berkontribusi dalam proses translokasi GLUT4 terutama jalur PI3K dapat berjalan dengan baik. Senyawa arekolin dalam pinang telah dibuktikan mampu menginduksi pengambilan 2-deoksiglukosa dalam L6myotube melaluipeningkatan ekspresi GLUT4 dan gen-gen yang terlibat dalam jalur PI3Kuntukproses translokasiGLUT4 tanpapenambahan insulin (Prabhakar \& Doble 2011). Pada penelitian ini diduga translokasi GLUT4 distimulasi oleh arekolin melalui jalur tidak tergantung insulin sehingga dapat meningkatkankeberadaan GLUT4 padamembran plasma sel-sel otot rangka. Peningkatan keberadaan GLUT4 pada membran plasma ini menginduksi pengambilan glukosa oleh sel-sel otot rangka mencit hiperglikemia yang diberi perlakuan ekstrak etanol biji pinang. Hal ini dibuktikan dengan adanya penurunan kadarglukosa darah dalam dua jam postprandial berdasarkan hasil tes toleransi glukosa meskipun kadar glukosa darah masih berada pada level yang tinggi. Meskipun arekolin diduga mampu menginduksi pengambilan glukosa melalui jalur PI3K tidak tergantung insulin, namun keberadaan insulin diduga mempengaruhi aktivitas GLUT4 secara fungsional sehinggaberkurangnyasekresi insulin akibat kerusakan pankreas dapatmenyebabkan pengambilan glukosa oleh GLUT4 tidak optimal dan keadaan hiperglikemiamasih tetap terjadi(Damasceno etal.2014)(Gambar 7). Hasil penelitian ini memberikan informasi bahwa ekstrak etanol biji pinang diduga kuat bersifat mampu mempertahankan homeostatis kadar glukosa darahmelalui peningkatan translokasi GLUT4 meskipun masih berada dalam keadaan hiperglikemia.

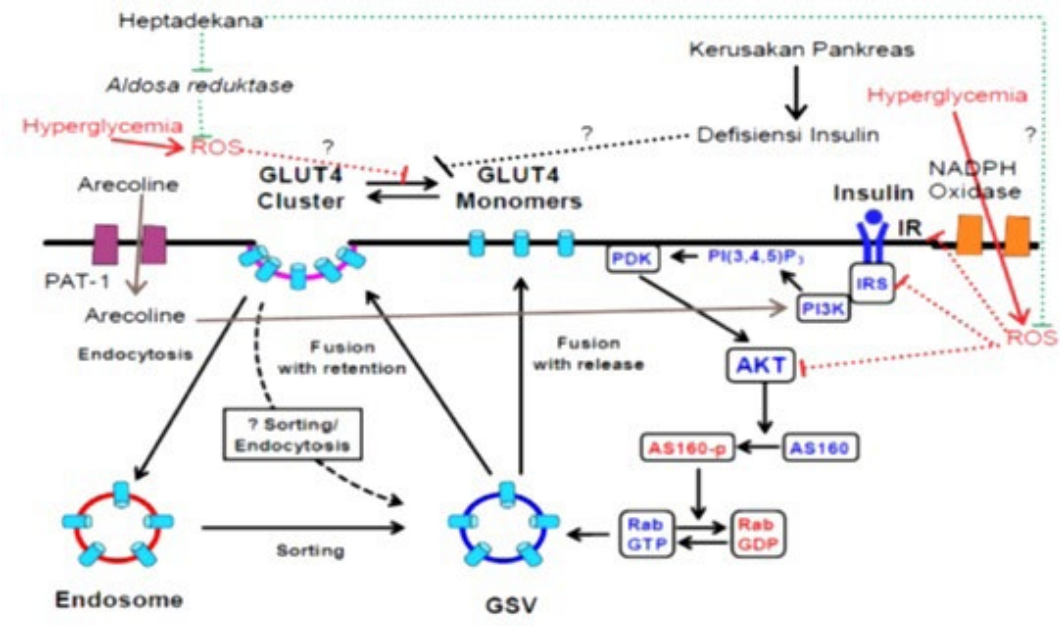

Gambar 7. Peranan arekolin dan heptadekana dalam translokasi GLUT4 (Modifikasi Prabhakar \& Doble 2011; Aleykutty 2012; Yang 2010) 
Penelitian berikutnya mengenai kuantitas insulin endogen yang disekresikan selama periode satu jam dan dua jam postprandial serta mekanisme aksi dari senyawa-senyawa dalam ekstrak etanol bijipinang dapat memberikan informasi tambahan tentang peran insulin terhadap fungsional GLUT4 dalam pengambilan glukosa dan peran senyawa-senyawa dalam ekstrak etanol biji pinang terhadap peningkatan translokasi GLUT4 terkait jalur PI3K.

Berdasarkan hasil penelitian yang telah diperoleh dapat disimpulkan bahwa ekstrak etanol biji pinang dapat berperan dalam meningkatkan densitas GLUT4 pada sel-sel ototrangka mencit yang diinduksi menjadi hiperglikemia dalam kondisi puasa dan satu jam postprandial dan dapat memperbaiki toleransi glukosa dalam kondisi dua jam postprandial meskipun kadar glukosa darah tetap berada di atas level glikemia normal.

\section{UCAPAN TERIMAKASIH}

Penulis mengucapkan terima kasih atas Beasiswa Tesis Disertasi yang diberikan oleh LPDPTahun 2016 dan SITH ITB serta semua pihak yang terkait.

\section{DAFTAR PUSTAKA}

Aleykutty NA. 2012. Docking studies on identified constituents of Helicteres isora as antidiabetic agents. International Journal of Computer Applications 45(20).

Anthikat RRN, Michael A, Vageesh S, Balamurugan R, Ignacimuthu S. 2014. The effect of Areca catechu. L. extract on streptozotocin induced hyperglycaemia in Wistar rats. Int $J$ Pharm Bio Sci 5:316-321.

Brownlee M. 2005. The pathobiology of diabetic complications a unifying mechanism. Diabetes 54(6):1615-1625.

Damasceno DC, Netto AO, Iessi IL, Gallego FQ, Corvino, SB, Dallaqua B, Sinzato YK, Bueno A, Calderon IDMP, Rudge MVC. 2014. Streptozotocin-induced diabetes models: pathophysiological mechanisms and fetal outcomes. BioMed research international 2014.

Djrolo F, Paraïso NM, Diarra O, Makoutode M. 2014. Diabetes complications and associated factors in type 2 diabetic patients in Cotonou. Journal of Diabetes Mellitus 4(04):311.

Eleazu CO, Eleazu KC, Chukwuma S, Essien UN. 2013. Review of the mechanism of cell death resulting from streptozotocin challenge in experimental animals, its practical use and potential risk to humans. Journal of Diabetes \& Metabolic disorders 12:60.

Elghazi L, Rachdi L, Weiss AJ, Cras-Méneur C, Bernal-Mizrachi E. 2007. Regulation of $\beta$-cell mass and function by the Akt/ protein kinase B signalling pathway. Diabetes, Obesity and Metabolism 9(s2):147-157.

Giugliano D, Ceriello A, Esposito K. 2008. Glucose metabolism and hyperglycemia. The American journal of clinical nutrition $87(1): 217 \mathrm{~S}-222 \mathrm{~S}$.

Govindappa M. 2015. A review on role of plant (s) extracts and its phytochemicals for the management of diabetes. Journal of Diabetes \& Metabolism 2015.

International Diabetes Federation. 2015. IDF Diabetes Atlas. Brussels: International Diabetes Federation.
Jensen A, Figueiredo-Larsen M, Holm R, Broberg ML, Brodin B, Nielsen CU. 2014. PAT1 (SLC36A1) shows nuclear localization and affects growth of smooth muscle cells from rats. American Journal of Physiology-Endocrinology and Metabolism 306(1): E65-E74.

Khorami SAH, Movahedi ARIYO, Khaza'ai HUZWAH, Mutalib A, Sokhini MOHD. 2015. PI3K/AKT pathway in modulating glucose homeostasis and its alteration in diabetes. $A M B S$ 1:46-55.

King GL, Park K, Li Q. 2016. Selective insulin resistance and the development of cardiovascular diseases in diabetes: The 2015 Edwin Bierman award lecture. Diabetes 65(6):1462-1471.

Mannan A, Rupa BA, Azam NK, Ahmed N, Hasan N. 2014. A quick review on anti-diabetic plants and action of phytochemicals. Inter $J$ Adv Res 2:227.

Mansour M, Salam RF, Rashed L, Salam H. 2014. Role of toll receptors in diabetic nephropathy. Journal of Diabetes Mellitus 2014.

Pichini S, Marchei E, Palmi I, Pellegrini M, Calapai G, Oteri A, Caveo V, Caputi AP, Klein J. 2010. Smart drugs - English edition. Roma: Istituto Superiore di Sanità.

Prabhakar PK \& Doble M. 2011. Interaction of phytochemicals with hypoglycemic drugs on glucose uptake in L6 myotubes. Phytomedicine 18(4):285-291.

Pradini A. 2010. The role of polyphenol on the presence of GLUT4 in skeletal muscle plasma membrane of diabeticinduced mice [Thesis]. Bandung: Institut Teknologi Bandung.

Ramesh R, AdhishwarKumaran N, KuzhandaiVelu V, Reeta R, SathishBabu M, Niranjan G. 2015. Association between hepato-biliary status and $\mathrm{HbA} 1 \mathrm{C}$ in type 2 diabetes mellitus with coronary artery disease (CAD). Journal of Diabetes Mellitus 5(02):67.

Sa'roni SR \& Adjirni A. 2005. Spesifikasi simplisia dan ekstrak etanol biji pinang (Areca catech $u \mathrm{~L}$ ) asal Tawangmangu serta toksisitas akut dan khasiat hemostatiknya pada hewan coba. Media Penelitian dan Pengembangan Kesehatan 15(1 Mar).

Spangler JG \& Kirk J. 2014. Correlation between diabetes prevalence and subsequent cancer mortality in North Carolina counties. Journal of Diabetes Mellitus 2014.

Tarr JM, Kaul K, Chopra M, Kohner EM, Chibber R. 2013. Pathophysiology of diabetic retinopathy. ISRN ophthalmology 2013.

Thamotharan M, McKnight RA, Thamotharan S, Kao DJ, Devaskar SU. 2003. Aberrant insulin-induced GLUT4 translocation predicts glucose intolerance in the offspring of a diabetic mother. American Journal of Physiology Endocrinology and Metabolism 284(5):E901-E914.

Voigt V, Laug L, Zebisch K, Thondorf I, Markwardt F, Brandsch M. 2013. Transport of the areca nut alkaloid arecaidine by the human proton-coupled amino acid transporter 1 (hPAT1). Journal of Pharmacy and Pharmacology 65(4):582-590.

Wei Y, Chen K, Whaley-Connell AT, Stump CS, Ibdah JA, Sowers JR. 2008. Skeletal muscle insulin resistance: role of inflammatory cytokines and reactive oxygen species. American Journal of Physiology-Regulatory, Integrative and Comparative Physiology 294(3):R673-R680.

Wild S, Roglic G, Green A, Sicree R, King H. 2004. Global prevalence of diabetes estimates for the year 2000 and projections for 2030. Diabetes care 27(5):1047-1053.

Yang J. 2010. Role of clusters in insulin-regulated GLUT4 trafficking in adipose cells: A new paradigm?. International journal of biological sciences 6(7):716.

Zhang WM, Huang WY, Chen WX, Han L, Zhang HD. 2014. Optimization of extraction conditions of areca seed polyphenols and evaluation of their antioxidant activities. Molecules 19(10):16416-16427. 